\title{
BASALT INTRUSIONS IN PALAEOKARST CAVES IN THE CENTRAL LESSINI MOUNTAINS (VENETIAN PREALPS, ITALY)
}

\author{
BAZALTNE INTRUZIJE V PALEOKRAŠKIH JAMAH V \\ CENTRALNIH LESSINIH (BENEŠKE PREDALPE, ITALIJA)
}

\author{
Guido GONZATO ${ }^{1}$, Guido ROSSI² \& Roberto CHIGNOLA ${ }^{3}$
}

\begin{abstract}
UDC 551.435.84:552.323(234.323.4)

Guido Gonzato, Guido Rossi \& Roberto Chignola: Basalt intrusions in palaeokarst caves in the central Lessini Mountains (Venetian Prealps, Italy)

The Lessini Mountains carbonate plateau (Venetian Prealps, Italy) is one of the most important karst areas in Italy. Along with alpine-type caves and well-developed karst landscapes, palaeokarst features are also common. In most cases, palaeokarst is represented by caves and fissures filled by limonitic-haematitic palaeosols (ochres) in which fossiliferous arenite layers are sometimes embedded. These features developed and fossilised during a late Eocene-middle Miocene phase of emersion. Between the Palaeocene and the Oligocene, over a time span partially overlapping the development of palaeokarst, basaltic volcanism took place in the Lessini Mountains. Along with ochre fills, cave passages that were intruded by basalt provide further evidence that a well developed karst network existed in the Lessini Mountains area in the middle-late Palaeogene. Moreover, basalt intrusions provide the only available data for the dating of palaeokarst in the central Lessini Mountains, where fossiliferous layers in ochre beds have not been found. We have started a new survey on palaeokarst in the Lessini plateau, with the aim of identifying ancient features on the basis of unusual fills (namely, ochre and basalt) and morphologies. New instances of basalt intrusions in three caves, Spigola di Canova, Covoli di Velo, and Covolo della Croce, have been recognised; evidence of pre-existing karst features filled by basalt in a previously studied cave (Grotta A Veja) has been identified, and an unusual basalt outcrop that might relate to palaeokarst has also been observed. This paper aims to document the new findings and to discuss previous ones. At the same time, we would like to point out some cautionary observations to prevent a "basalt = palaeokarst" misunderstanding.
\end{abstract}

Key words: palaeokarst, basalt intrusion, cave fills, Lessini Mountains.

\author{
Izvleček \\ UDK 551.435.84:552.323(234.323.4) \\ Guido Gonzato, Guido Rossi \& Roberto Chignola: Bazaltne \\ intruzije v paleokraških jamah v centralnih Lessinih (Beneške \\ Predalpe, Italija)
}

Karbonatna planota Mt. Lessini (Beneške Predalpe, Italija) je eno od najpomembnejših kraških območjih v Italiji. Poleg jam alpskega tipa in značilno oblikovane kraške pokrajine so tu pogosti tudi paleokraški pojavi. Za paleokras so večinoma značilne jame in razpoke, zapolnjene $z$ limonitno-hematitnimi paleotlemi (»okra«), v katerih so ponekod vključene s fosili bogate plasti arenitov. Ti pojavi so se razvili in fosilizirali v času zgornje eocenske do srednje miocenske emerzije. Med paleocenom in oligocenom, torej $\mathrm{v}$ obdobju, ki se delno prekriva $\mathrm{z}$ razvojem paleokrasa, je bil na območju Lessinov dejaven tudi bazaltni vulkanizem. Tako poleg »okre« dokazuje obstoj dobro razvitega kraškega podzemlja $\mathrm{v}$ času srednjega-poznega paleogena tudi bazalt, ki zapolnjuje nekatere že oblikovane jamske rove. Kjer v »okri« niso našliplasti s fosili, so bazaltne intruzije edine kamnine, primerne za datacijo paleokrasa v osrednjih Lessinih. Da bi pojasnili nastanek starih kraških oblik, smo začeli na Lessinski planoti na podlagi nenavadnih polnil (»okra" in bazalt) in morfologije nove raziskave paleokrasa. V treh jamah (Spigola di Canova, Covoli di Velo in Covolo della Croce) smo našli nove primere bazaltnih zapolnitev. $V$ že raziskani jami Grotta Veja smo potrdili obstoj predhodnih kraških oblik, zapolnjenih z bazaltom. Evidentirali smo tudi nenavaden izdanek bazalta, ki ga po vsej verjetnosti prav tako lahko povežemo s paleokrasom. Namen tega prispevka je bil dokumentirati nove najdbe paleokrasa in razpravljati o že znanih, hkrati pa bi radi opozorili na nekatere ugotovitve, s katerimi bi radi preprečili napačno razumevanje odnosa »bazalt $=$ paleokras".

Ključne besede: paleokras, bazaltne intruzije, zapolnitve jam, Mt. Lessini.

\footnotetext{
${ }^{1}$ Unione Speleologica Veronese, Via Bionde 61, 37139 Verona, Italy, e-mail: guido.gonzato@gmail.com

${ }^{2}$ Museo di Storia Naturale di Verona, Lungadige Porta Vittoria 9, 37129 Verona, Italy

${ }^{3}$ Dipartimento di Biotecnologie, Università di Verona, Italy

Received/Prejeto: 24.4.2016
} 


\section{INTRODUCTION}

The Lessini Mountains are parts of a carbonate plateau lying at the southern edge of the Venetian Prealps, bordering the Po Plain north of Verona (south-eastern Alps, Italy; Fig. 1). The plateau is one of the most important Italian karst areas, comprising over 750 mapped caves and, at its higher altitudes, well developed karst landforms (Sauro 1973; Mietto \& Sauro 2000). A detached section of the plateau, emerging from the Po Plain near Vicenza, is called Berici Mountains.

The presence of widespread palaeokarst features in the Lessini Mountains is well known, although not yet exhaustively documented. These features are especially developed in the southern part of the plateau, precisely in the Torricelle hills surrounding Verona. Here, a palaeokarst cave network estimated to extend at least $20 \mathrm{~km}$ developed in late-Eocene limestones and marls (Forlati 1978). These caves are fossilised by limonitic palaeosols, mostly silt and clay; well preserved foraminifera assemblages found in calcarenite layers embedded in the fills yielded a late Eocene to middle Miocene age (Corrà 1977; Zorzin et al. 1992; Gonzato et al. 2014).
Other palaeokarst caves and the presence of palaeokarst-related ochre fills have been reported in the central Lessini Mountains (Scarzella \& Natale 1989; Zorzin 2005). Basalt intrusions in cave passages have also been reported, providing further evidence for palaeokarst; local volcanism, in fact, ended in the late Oligocene. The only evidence of a basalt intrusion in the Lessini Mountains was described at the Covoli di Velo cave complex (Rossi \& Zorzin 1986, 1993; Sauro 2001). In the Berici Mountains, Grotta della Guerra contains some basalt filled passages that have been tentatively interpreted as intrusions (Dal Molin et al. 2000). Another unconfirmed finding is Grotta A at the Ponte di Veja geosite (Rossi \& Zorzin 1993).

We have started a new survey on palaeokarst in the central Lessini plateau, paying particular attention to the presence of basalt fillings, possibly flows, in caves. We have revisited Covoli di Velo, where we have found a new cave branch containing a basalt filled conduit. We have also managed to find strong evidence of pre-existing karst features in the basalt filled passage at Grotta

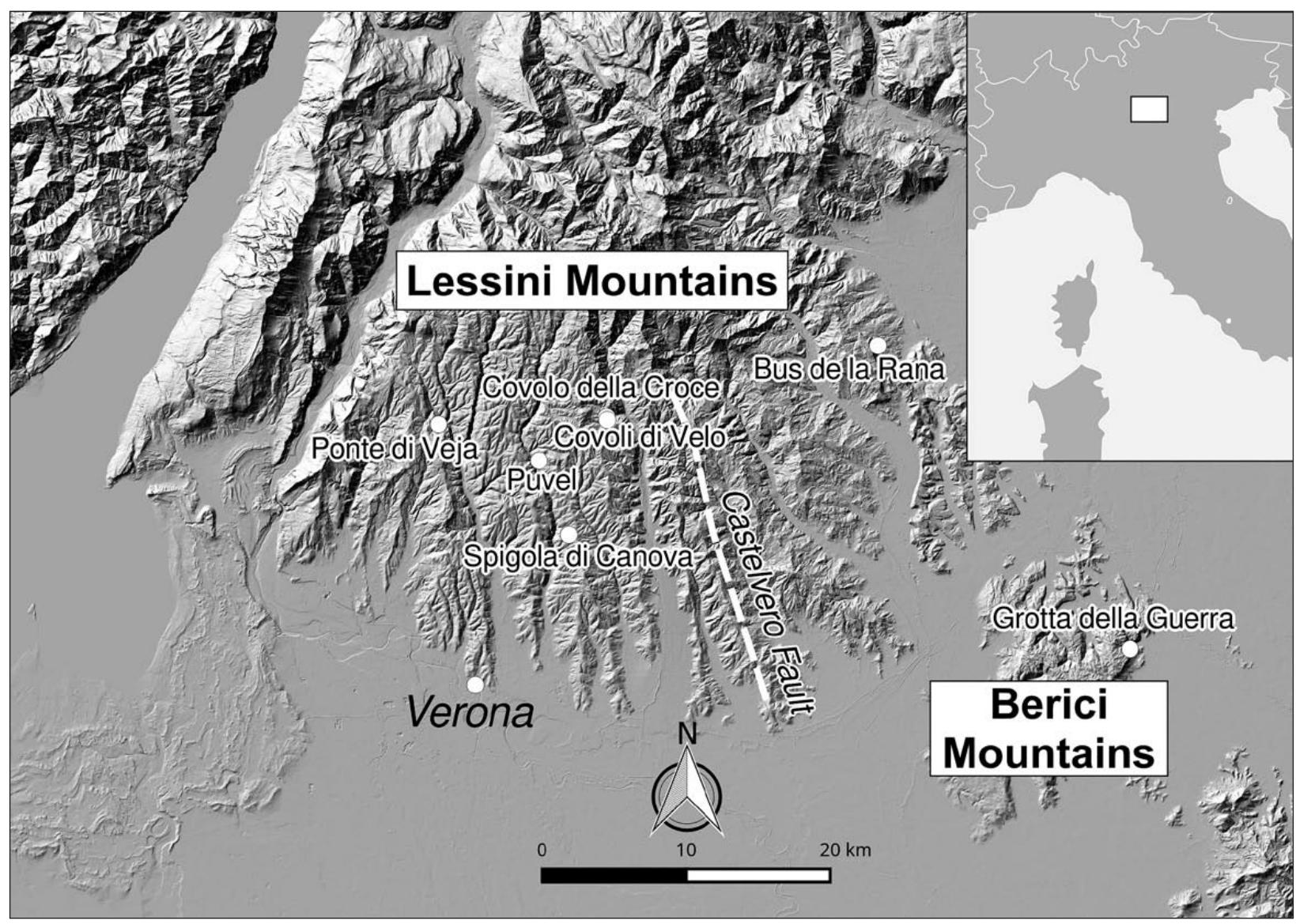

Fig. 1: Geographical setting of the study area. DEM data after Tarquini et al. (2007). 
A Veja. Furthermore, we report on previously neglected basalt intrusions that we have found in the caves Covolo della Croce and Spigola di Canova. Finally, we compare these proved instances of basalt intrusions in palaeokarst caves to other ambiguous findings, underlining that the implication "basalt in a cave means palaeokarst" cannot always be taken for granted.

\section{GEOLOGICAL SETTINGS}

The sequence of sedimentary rocks in the central Lessini plateau is more than $1500 \mathrm{~m}$ thick, and it includes carbonate formations ranging from the late Triassic to the early Eocene. The plateau is slightly tilted southwards; Cenozoic Formations outcrop mainly in the southern part, while Jurassic and Cretaceous Formations are the main lithology in the central and northern Lessini Mountains (Antonelli et al. 1990).

From bottom to top, the stratigraphic column of the study area includes the upper part of the Calcari Grigi Group (mainly mudstone and oolitic limestone; Hettangian-Pliensbachian), San Vigilio Group (mudstone and oolitic limestones; Toarcian-Alenian), Rosso Ammonit-

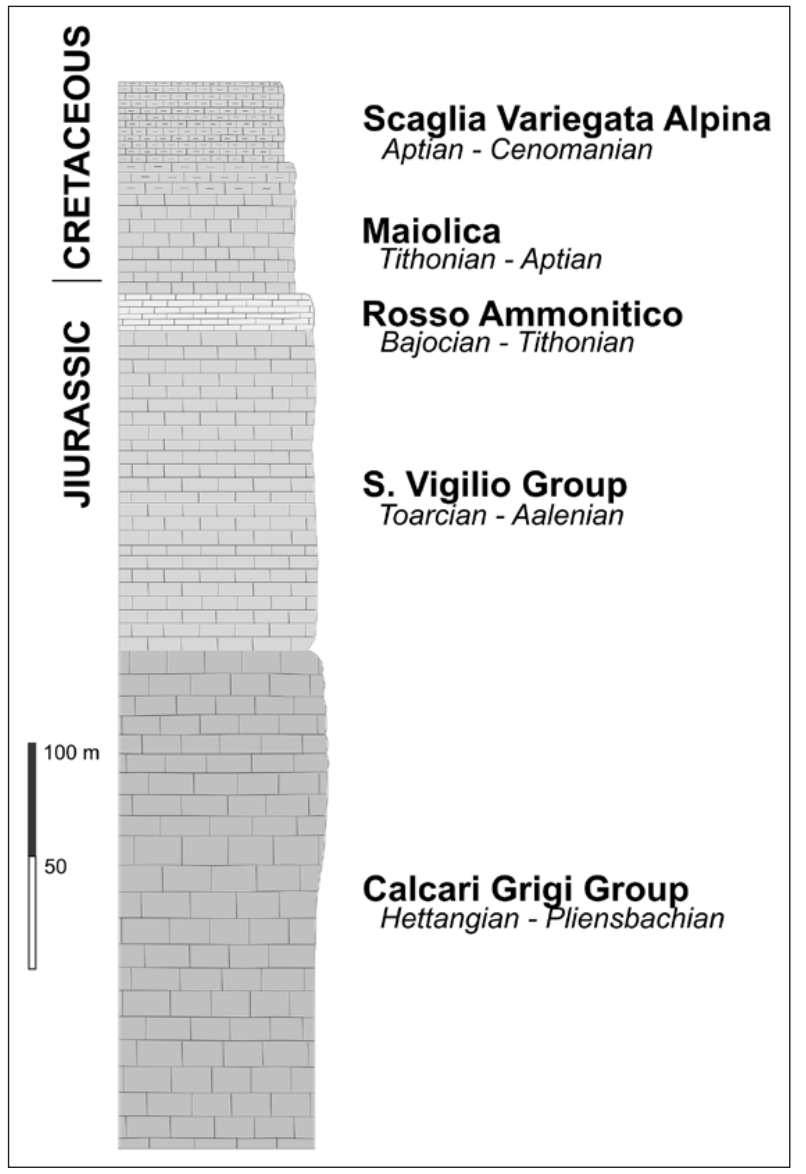

Fig. 2: Stratigraphic column of the study area. ico (nodular mudstone; Bajocian-Tithonian), Maiolica (marly limestone and marl; Tithonian-Aptian) and Scaglia Variegata (marl and clay; Aptian-Cenomanian); see Fig. 2.

Extensive fracturing induced by tectonics facilitated the development of epigenic karst. Most caves develop in Calcari Grigi, San Vigilio, and Rosso Ammonitico. Karst in Maiolica is much less developed, primarily because of its weak mechanical properties. In fact, Maiolica beds are heavily fragmented by tectonics, hence lacking the mechanical capability to sustain caves. Moreover, diffuse circulation is dispersed through a fracture network that lacks speleogenetic capabilities (Sauro 1974). Therefore, karst in Maiolica is mostly represented by dolines, sometimes leading to caves developed in the Rosso Ammonitico underneath. Scaglia Variegata is fairly rich in clay and is minimally karstified; along with the upper part of Maiolica, it tends to act as an aquitard.

Tectonic lineages have a NNE-SSW direction in the western part of the plateau, parallel to the Giudicarie fault system (related to Serravallian-Tortonian compressional events); moving eastwards, the plateau is affected by NW-SE transfer faults (Schio-Vicenza system), related to Messinian to Pliocene events (Castellarin \& Cantelli 2000; see also Antonelli et al. 1990). The result is a characteristic fan-like pattern, deeply incised by local valleys (Sauro 2010).

The Formations are crossed by necks, sills and dykes of Palaeocene-Eocene basalt; submarine eruptions also deposited tuff and hyaloclastite beds. In addition to major basalt necks, up to a few hundred metres across, thin basalt dykes are very common. They are often associated with fault lines and their thickness varies from a few centimetres to a few decimetres. To the east of the Castelvero Fault, Oligocene volcanic rocks become prevalent (Piccoli 1966).

A stratigraphic gap extending from the upper Eocene to the lower Miocene affects the southern edge of the Lessini Mountains. Erosional surfaces, products of subaerial weathering of rocks, and palaeokarst allow the gap to be attributed to a subaerial period of Oligocene age (Fabiani 1919; Conato \& Martinis 1955; De Zanche et al. 1977). The stratigraphic gap is limited to an area 
enclosed to the west by the Adige valley and to the east by the Agno valley.

The most common sediments that testify to subaerial weathering of rocks are haematitic and limonitic palaeosols, filling palaeokarst fissures and cavities. In the central Lessini Mountains, palaeosol-filled karstic cavities developed along the boundary between the Oolite di San Vigilio Group and the Rosso Ammonitico Formation; in the Torricelle hills, they developed in late Eocene limestones.

\section{PREVIOUS STUDIES}

The presence of lava flows in karst caves is an uncommon phenomenon that has been rarely reported. Even prominent literature on palaeokarst describes several types of sediment fills in palaeokarst caves, but does not cite lava flows (see for instance James \& Choquette 1989; Bosák et al. 1990). A basalt flow was reported by Osborne (1986) at Timor Caves (New South Wales, Australia); this finding was further discussed in his later works and employed as a case study for the distinction between flows and ordinary fills (Osborne 2005 and references therein).

In some caves in Italy, instances of basalt flows in karst features have been described. In particular, one of the caves at Cala di Luna (eastern Sardinia) was flowed over by Quaternary basalt (Assorgia et al. 1968); the same phenomenon also occurred at Grotta del Bue Marino (Cala Gonone, eastern Sardinia; Mahler 1979), intruded by Pliocene basalt. Another significant instance of lava-filled karst conduit was described by Riva (2014) in the middle Triassic hypogene palaeokarst of Latemar in the Dolomites.

Studies on basalt intrusions in Lessinian caves are very limited. The first account of a certain basalt intrusion in a cave was given by Rossi and Zorzin (1986), who briefly described the outcrop at Covolo Inferiore in the Covoli di Velo cave system. In this cave the Authors found a small chamber that was originally completely filled by basalt. At the sides of the chamber the remaining basalt seals a ceiling channel, indicating that this paragenetic feature pre-dates the basalt intrusion. K-Ar radiometric dating yielded an age of $33 \pm 1.5 \mathrm{Ma}$ for the basalt (Rossi \& Zorzin 1991). In the vicinity of this site, Sauro (2001) also reported another karst conduit filled by basalt.

Another basalt outcrop, doubtfully attributed to intrusions in pre-existent karst voids, was reported at Grotta della Guerra in the Berici Mountains (Dal Molin et al. 2000). The formation of this cave is thought to be related to late-Oligocene volcanism; in many passages the vault is shaped by coalescent cupolas of supposedly hydrothermal origin (Dal Molin et al. 2000). There are a few passages that end in basalt; their rounded geometry suggests that they could be intruded and thus sealed by basalt. However, unlike the outcrop at Covoli di Velo, there is no unequivocal evidence (such as filled ceiling channels) to support this interpretation. The third supposed basalt intrusion was reported at Grotta A Veja (Rossi \& Zorzin 1993). In this case too the Authors maintained that a basalt dyke intruded a fairly large pre-existing karst cave, overlapping karst morphologies.

The following sections describe some occurrences of basalt filled cave passages that can be interpreted as intrusions with a high degree of confidence.

\section{RESULTS}

\section{BASALT INTRUSIONS AT COVOLI DI VELO}

Covoli di Velo is a group of four major caves and minor cavities which extend for a few hundred metres, near Velo Veronese (Fig. 3). Some of them are partly filled by Pleistocene sediments containing numerous remains of Ursus spelaeus and other mammalians. Palaeontologists have been studying this site since the end of the $18^{\text {th }}$ century (Fortis 1785-1786; Benetti 1973; Benetti \&
Sauro 1999; Mietto \& Sauro 2000; Zorzin \& Rossi 2006, and references therein). Other findings indicate that the formation of the karst complex predates even the Quaternary; in particular, basalt and ochre fillings in a few passages.

We re-examined the main caves, Covolo Inferiore and Covolo Superiore, and took part in a new cave survey. The caves share a common entrance, which is filed as n. 44-V-VR in the Veneto Cave Registry 


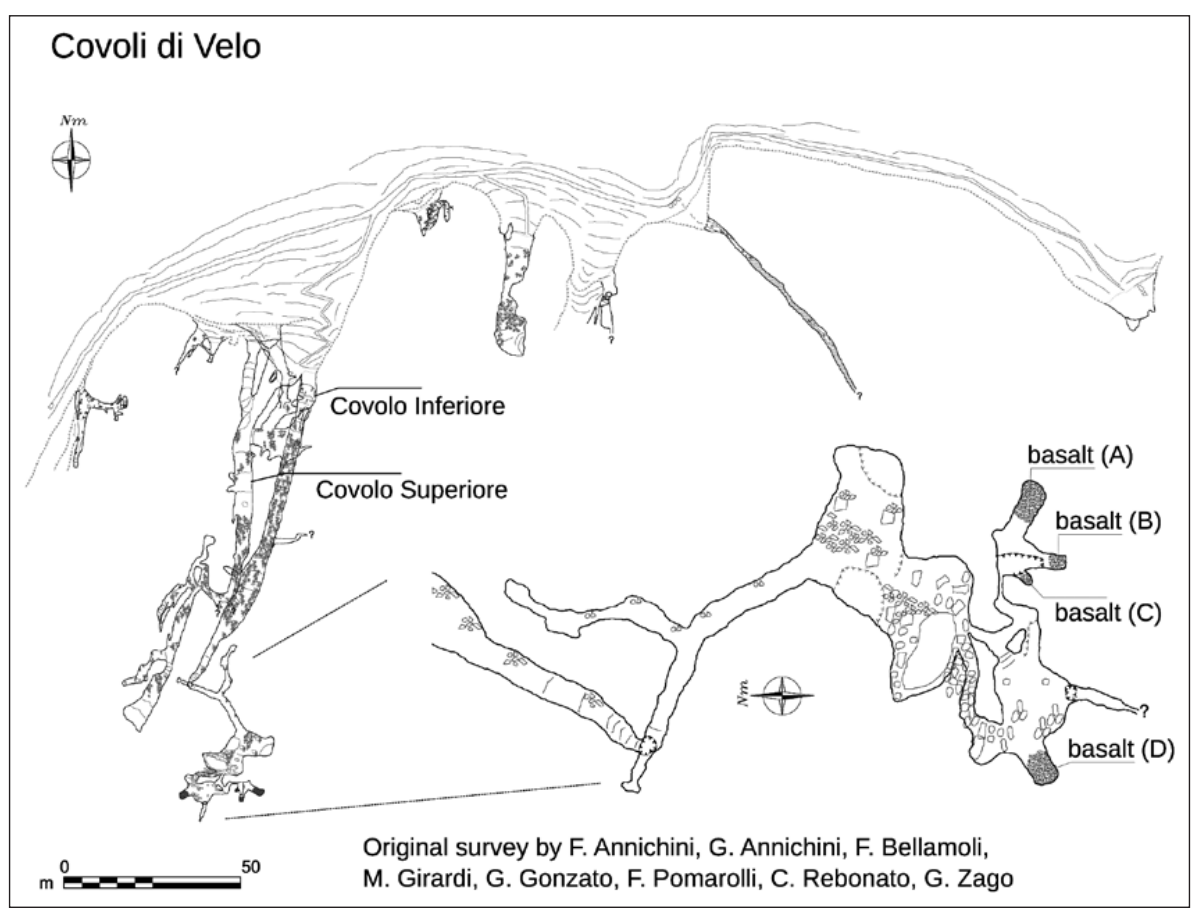

Fig. 3: Plan and profile view of Covolo Inferiore and Covolo Superiore. Basalt intrusions marked $A-D$ are displayed in Fig. 4.

and is located at WGS84 coordinates N 45.608203, E 11.119853, elevation $878 \mathrm{~m}$. Lithology: Calcari Grigi oolithic limestone.

The presence of a basalt intrusion was first reported by Rossi and Zorzin (1986); the new survey has revealed a new outcrop and new details. Access to Covolo Inferiore is restricted, since archaeological excavations are still in progress; as a result, very few cavers have had the opportunity to improve the existing decade-old survey and make new observations.

Four basalt outcrops can be spotted at the end of Covolo Inferiore, where they fill three rounded passages and a small conduit (Fig. 4A-D).

The largest outcrop, $2 \mathrm{~m}$ across and $1 \mathrm{~m}$ tall, is found at the sides of a short chamber that has a $25 \mathrm{~cm}$ wide channel on its ceiling. Fragments of basalt are still stuck in the channel, showing that the chamber was originally completely filled. The other two passages have smaller (approx. $5 \mathrm{~cm}$ across) ceiling channels that can be clearly seen in the basalt cross-section and, less clearly, on the ceiling of the empty passages. In all the outcrops the basalt is rather altered and tends to crumble. The ceiling of the main basalt filled passage develops at a bedding plane, and it is tilted $18^{\circ}$ towards SW.

The geometry of the passages and the presence of paragenetic features provide strong evidence of the basalt having intruded the karst voids. Moreover, it should be noted that Covolo Inferiore is now in a completely vadose stage of development; the water table is over $400 \mathrm{~m}$ below the cave, a few metres beneath the floor of the Val d'Illasi valley, opposite the Covoli complex. The ceiling channel, a feature that in this case formed horizontally in the epiphreatic zone, must have developed prior to tectonic uplift. This observation alone points to a preQuaternary date for this part of the cave; in fact, uplift of the Lessini Mountains, all along the rest of the Southern Eastern Alps, started in the Eocene (Castellarin \& Cantelli 2000).

During the new survey we managed to pass through a previously disregarded crawlway; a new chamber was found, showing a fourth basalt filled passage (Fig. 4D). Like the others described above, the passage has a clearly rounded morphology; in this case, it does not have a ceiling channel. Also in this case, the basalt is altered; traces of it are stuck on the top of a $40 \mathrm{~cm}$ wide cupola near the end of the passage. The limestone enclosing the basalt has turned into gray marble.

Another previously overlooked basalt outcrop, $6 \mathrm{~m}$ long and at most $30 \mathrm{~cm}$ thick, was also observed on the vault of the main passage. In this case the morphology is not rounded and is reminiscent of a thin vertical dyke. The basalt is heavily oxidised; it has been completely altered into incoherent yellow-brown ochre along the contact with the host rock, and into red ochre at the core. We found yellow ochre layers and pockets at some spots in the nearby Grotta Superiore, with no visible basalt in the vicinity.

\section{BASALT INTRUSIONS AT COVOLO DELLA CROCE}

Covolo della Croce, also known as Tana delle Sponde, is located less than $200 \mathrm{~m}$ to the north of Covoli di Velo at 


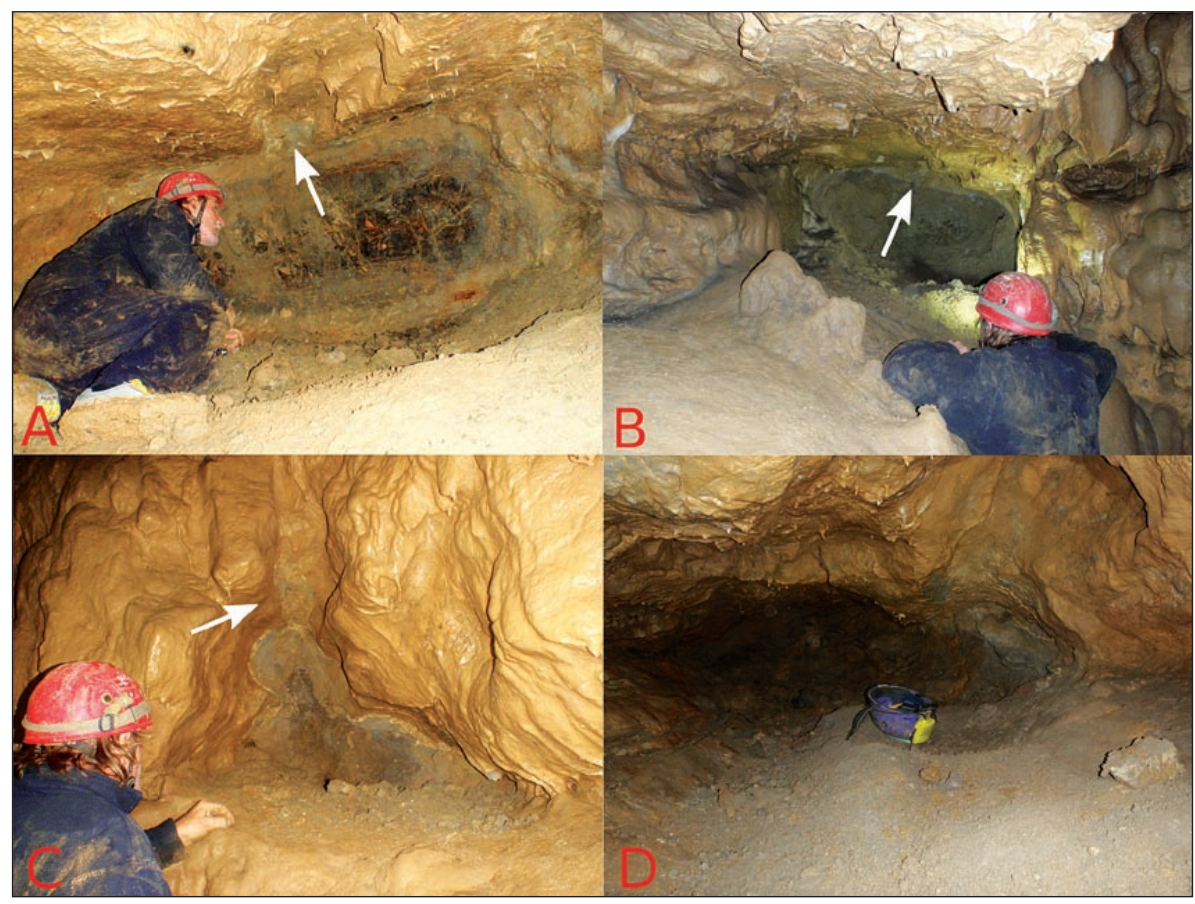

Fig. 4: Covoli di Velo: cross sections of the basalt-filled conduits in Covolo Inferiore, showing the rounded morphologies. Arrows point to the ceiling channels referred to in the text. The location of the four outcrops $A-D$ is marked in Fig. 3.

coordinates N 45.610056, E 11.119861, elevation $857 \mathrm{~m}$ (Fig. 5). It is filed as $85-\mathrm{V}-\mathrm{VR}$ and it develops in Calcari Grigi mudstone.

This well-known cave was briefly described by Pasa (1954), and consists of a collapse dome that leads to narrow passages exhibiting vadose, paragenetic, and collapse morphologies; thick clay deposits obstruct pockets and minor passages. Previously unreported basalt-filled pockets and small conduits were identified; as at Covoli di Velo, the outcrops are well confined and have clearly solutional morphologies (Fig. 6A-D). In all outcrops, the basalt is almost completely argillified and oxidised through contact with the host rock; at one spot, vesicular fabric is still visible.

A $10 \mathrm{~cm}$ across, $50 \mathrm{~cm}$ tall basalt-filled vertical pocket was found on the wall of the lower passage (Fig. 6A); at the bottom, the pocket is filled with clay. More interesting basalt outcrops were seen on the vault of the main passage; they consist of partially collapsed small conduits and a cupola-like pocket (Fig. 6B-D). Remarkably, one of the infills embeds a clast that, apparently, is the tip of a broken stalactite (Fig. 6B); another passage is a perfectly tubular conduit, less than $10 \mathrm{~cm}$ across (Fig. 6C, lower left). Also in this case, the rounded morphologies and

\section{Covolo della Croce}

Survey: D. Carli, V. Festa (U.S.V.)
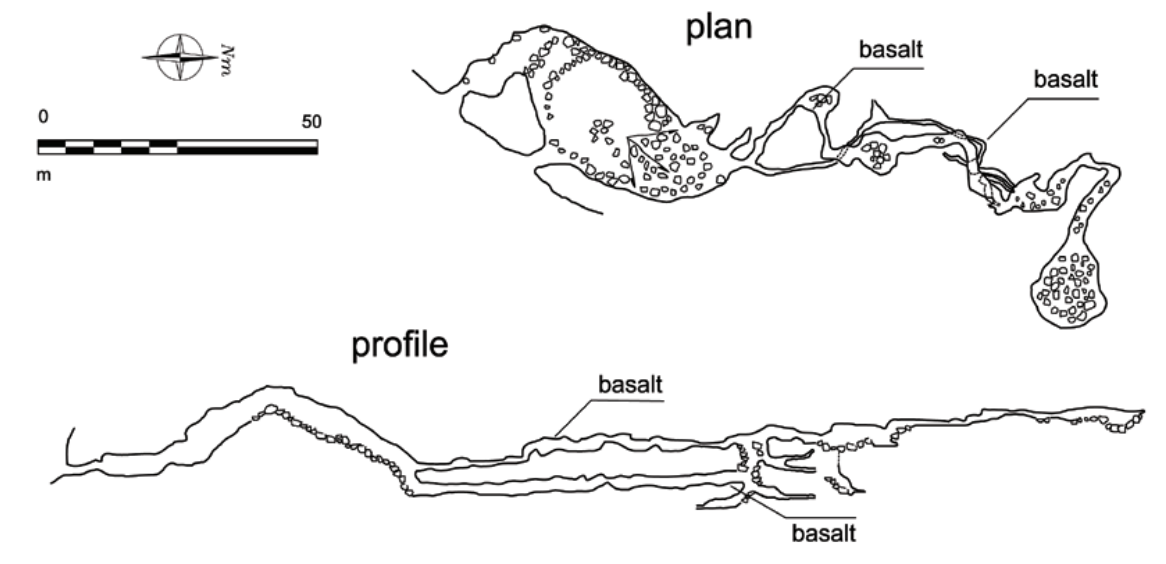

Fig. 5: plan and profile view of Covolo della Croce. Basalt intrusions are displayed in Fig. 6. 


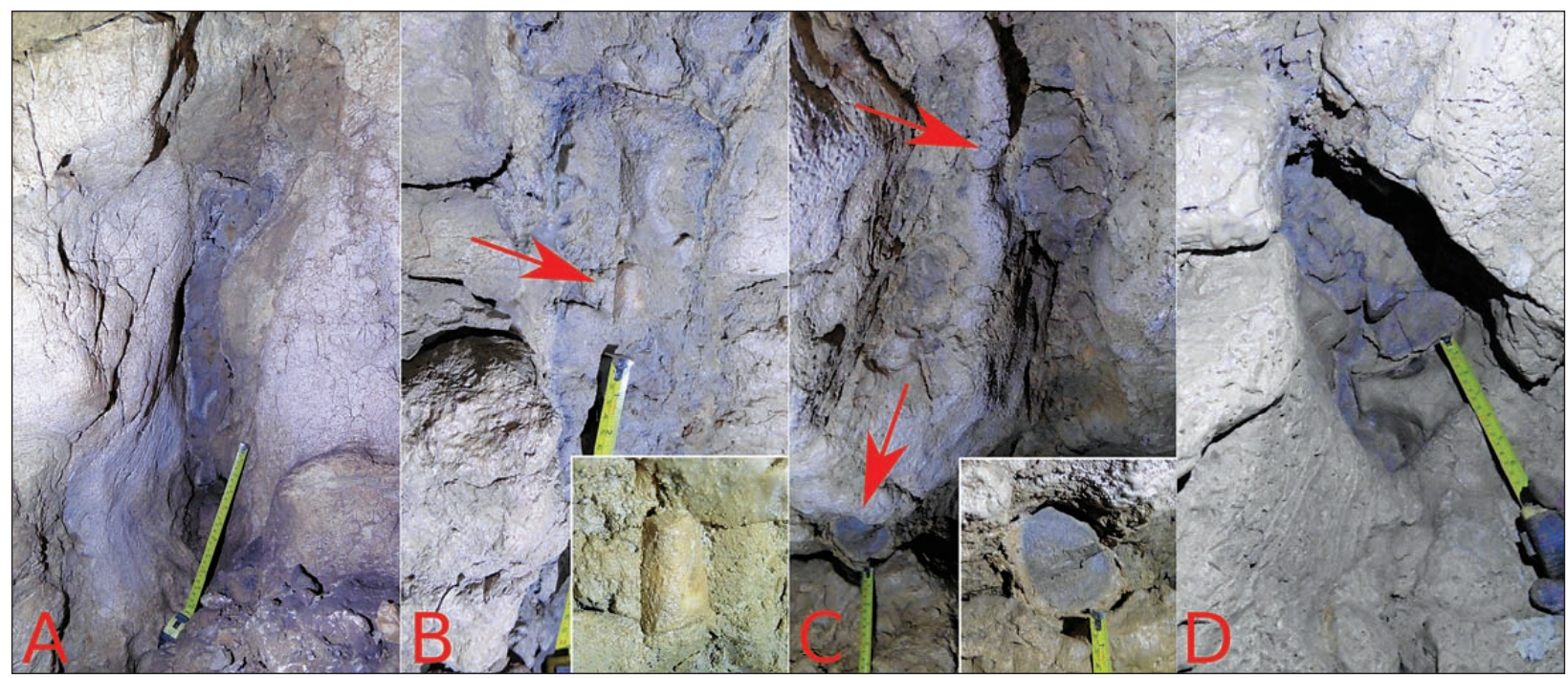

Fig. 6: basalt intrusions at Covolo della Croce, lower passage ( $A$ ) and main passage (B, $C, D)$. Arrow in B points to a stalactite fragment embedded in the basalt (inset: detail); arrows in $C$ point to the rounded basalt-filled conduit (inset: detail); solutional rounded surfaces (D), partially filled by basalt, in a ceiling cupola-like pocket.

the embedded stalactite fragment clearly show that these passages are karst voids intruded by basalt.

\section{BASALT INTRUSIONS AT SPIGOLA DI CANOVA}

Spigola di Canova is one of the very few Lessinian caves developed in the lower Maiolica Formation. The cave is filed as 483-V-VR, coordinates N 45.536020, E 11.085000, elevation $568 \mathrm{~m}$ near S. Rocco (Fig. 7). It was first surveyed and described by Pasa (1954), who reported the presence of a "basalt dyke" in parts of the cave. A fresh survey revealed that the "dyke" is most probably a basalt flow in karst voids.

On the bottom of a collapsed doline two $8 \mathrm{~m}$ deep pits lead to a dome-shaped chamber from which a few

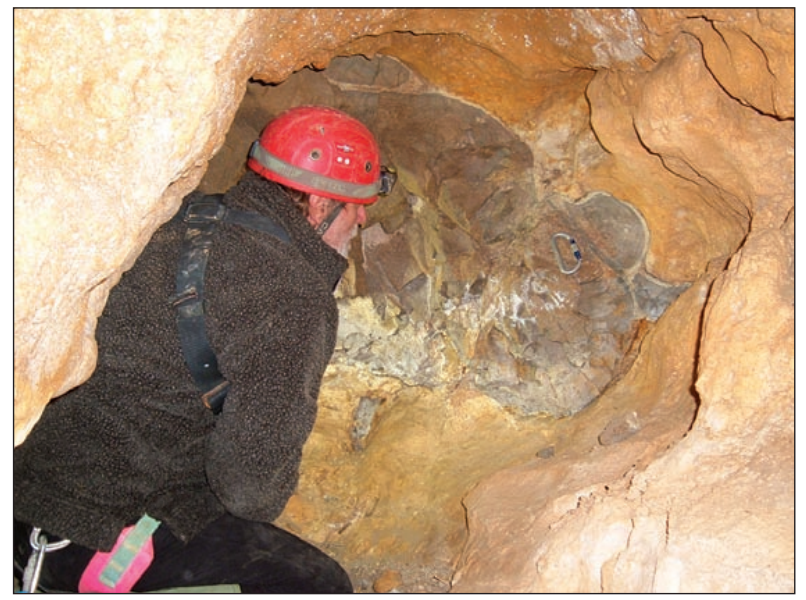

Fig. 8: Spigola di Canova: cross section of the northern basalt-filled passage. Note the rounded morphology and solution pockets. short and narrow passages branch outwards. Outcrops of crumbling basalt are visible in two passages. The first is a cupola-shaped niche with some basalt on its floor; apparently, the cupola was originally completely filled. The other passage has a vaguely rounded section that points to a phreatic origin; the basalt fills the end of it, sealing a few solution pockets (Fig. 8). The basalt is oxidised along the contact with the host rock, which is not recrystallised.

Unlike the basalt filled passages at Covoli di Velo there are no ceiling channels or other features that could represent conclusive evidence of karst morphology. However, these outcrops do not possess the typical features of a dyke, such as parallel faces and sheet-like geometry. We suggest that overall, the morphologies of the passag-

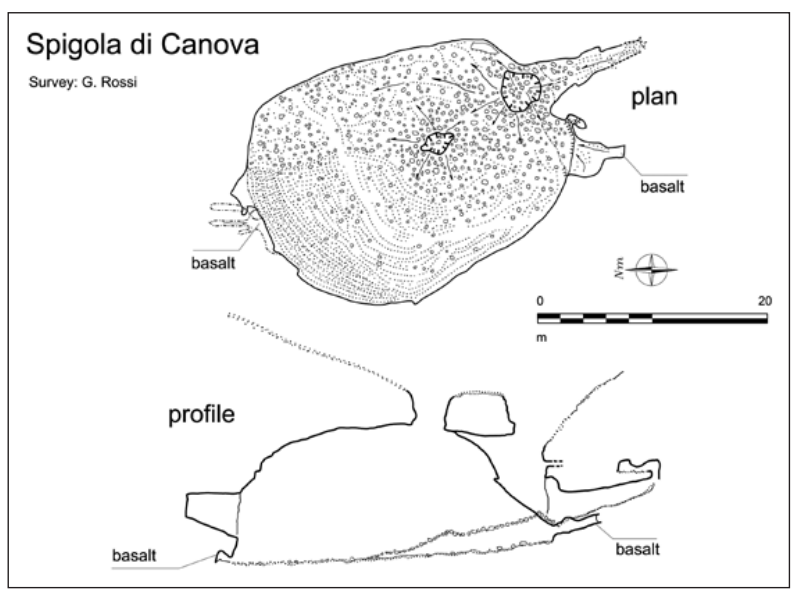

Fig. 7: Plan and profile view of Spigola di Canova. In plan view, the surrounding doline rim was omitted. 


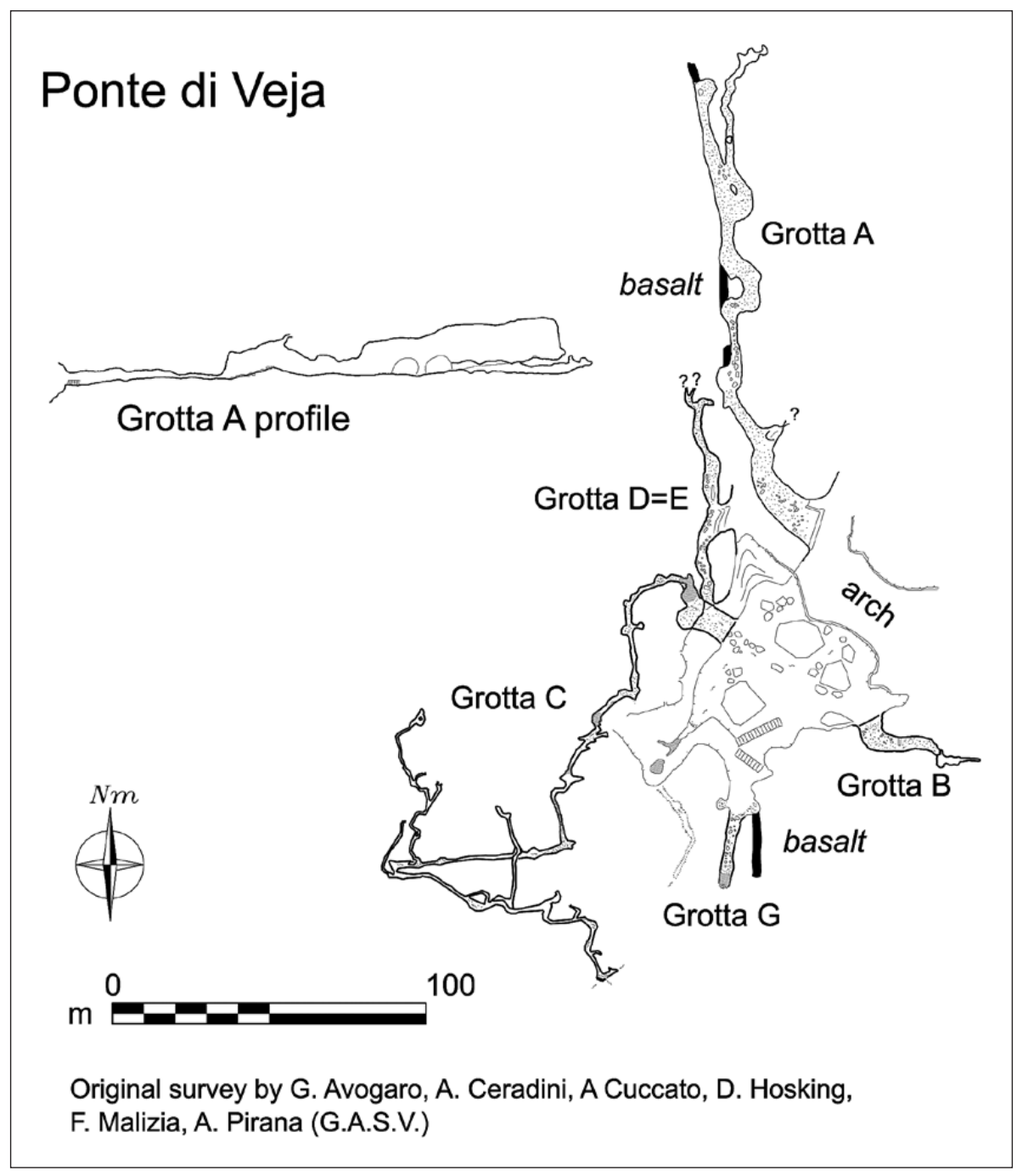

Fig. 9: Plan view of the Ponte di Veja geosite caves. Basalt outcrops (black-filled patches) are visible at Grotta $A$ and near Grotta G.

es, associated with the basalt intrusions at Covoli di Velo, strongly point to a pre-existing karstic origin.

\section{BASALT DYKE AT GROTTA A VEJA}

The "dyke or intrusion in karst" riddle is even more puzzling in the case of another well-known cave in the Lessini Mountains. The Ponte di Veja geosite, near Sant'Anna d'Alfaedo, consists of a natural arch surrounded by several caves. The arch is the surviving section of the vault of a large collapsed cave which developed at the boundary between the San Vigilio and Rosso Ammonitico Formations (Pasa 1950; Pasa 1954; Mietto \& Sauro 2000). The surrounding caves were named with single letters, from "A" to "G" (Fig. 9).

Grotta $\mathrm{D}=\mathrm{E}$ and Grotta $\mathrm{G}$ are probably the surviving segments of the same conduit, cut and exposed by erosion. These are known palaeokarst caves that were filled by limonithic laminated silt and breccia, cemented by microcrystalline quartz at some spots. This material was excavated until the end of the last century and used as pigment (Cavallo et al. 2015).

Owing to its unusual morphologies and archaeological importance, Grotta A is the most remarkable cave of the geosite. It is filed as n. 117-V-VR, coordinates N. 45.608198, E 10.970090, elevation $583 \mathrm{~m}$. Access to the cave is restricted; like Covoli di Velo, it is partly filled with silt and debris that yielded late Palaeolithic industries and mammalian remains (Pasa 1950; Broglio et al. 1963; Bartolomei \& Broglio 1975).

The main gallery is a rounded phreatic tube, approximately $5 \mathrm{~m}$ across, connected to a slightly wider, $12 \mathrm{~m}$ tall slot-shaped conduit. The vault of the tube is deeply shaped by coalescent cupolas; the passage walls are carved by notches and metre-sized rounded pockets, which we interpret as mega-scallops (Fig. 10). Basalt clogs the vault, and is also visible at the end of the conduit and in some other places; apparently, the conduit was originally completely filled by basalt that later crumbled 
away. The overall shape of this passage is similar to that of a dyke, even though the wall carvings and the variable width make a difference. At some places near the vault, basalt seems to overlap and fill the mega-scallops; unfortunately, these important spots are scarcely visible from the bottom.

Whether the dyke intruded an existing cave or whether the cave developed around the dyke has been a baffling problem. The former possibility was suggested by Rossi and Zorzin (1993); according to those Authors, the mega-scallops pre-existed the dyke, since the basalt seemed to overlap them. In our opinion, stronger evidence was needed to substantiate this claim.

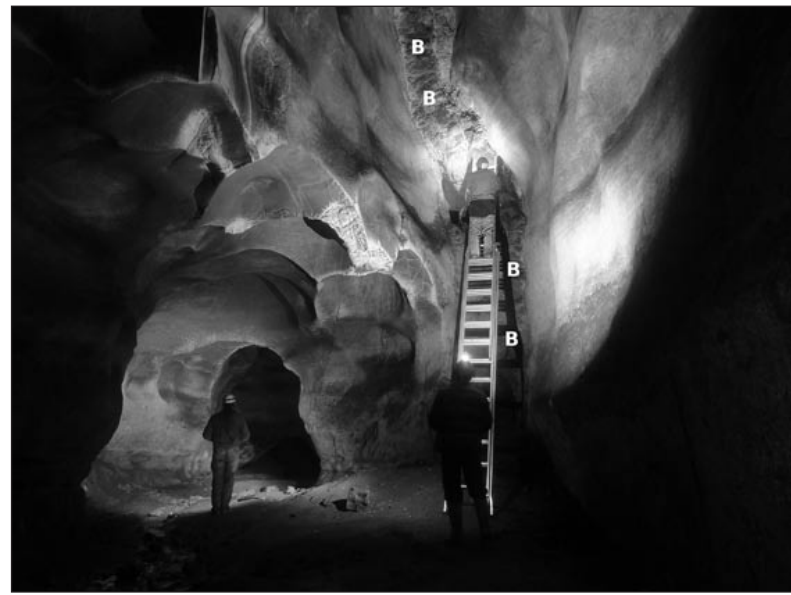

Fig. 10: Ponte di Veja Grotta A: the main passage. The phreatic tube is visible on the left; on the right, the basalt intrusion (marked with "B") fills part of the slot-shaped passage. Note the cupolas and the mega-scallops shaping the tube vault and the passage walls underlined by a sharp morphological change.

We then performed a new survey, with the aim of identifying places where the basalt unequivocally filled and/or overlapped karst features. We reached the passage vault and we luckily found such spots. In addition to wall carvings directly overlapped by basalt, we observed two cupolas that are still partially filled (Fig. 11) and another empty cupola that has traces of basalt on its top. Furthermore, we observed a stretch where vertical laminations of ochraceous silt drape over and partially fill some of the wall carvings; the ochre, in turn, is overlapped by basalt (Fig. 12). In these cases, the presence of clear karst features that existed prior to the basalt intrusion is undisputed.

The overall characteristics of this cave are strikingly similar to those described at Grotta della Guerra (Dal Molin et al. 2000). Both caves exhibit widespread cupolas and wall notches; basalt intrusions of variable thickness fill voids that show karstic morphology; basalts are oxidised and have been mostly eroded; cupolas are often truncated by passages that were filled by basalt. No other known caves in the area possess this set of features. The possibility that thermal fluids (possibly associated to volcanic activity) contributed to the karst development of Grotta della Guerra and Grotta A Veja is an intriguing hypothesis that needs further investigation.

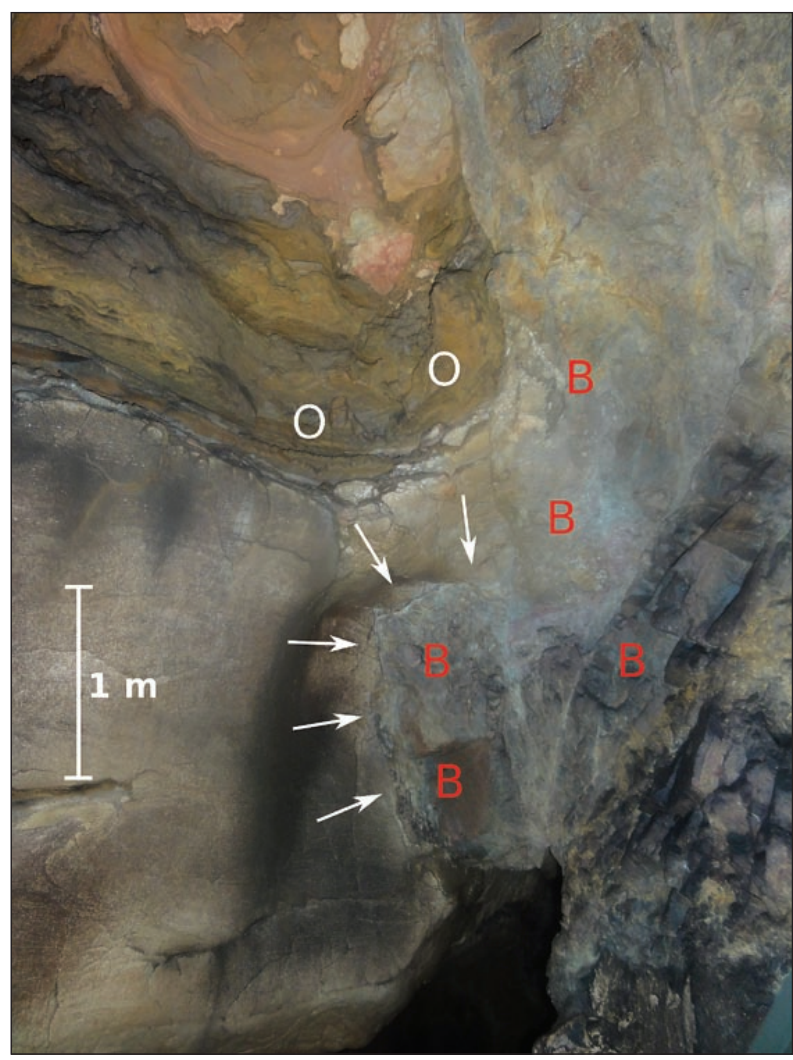

Fig. 11: Ponte di Veja Grotta A: detailed view of the vault of the main passage. Ochre laminations (marked by "O") are in contact with the basalt intrusion (marked by " $B$ "), which fills the cupola pointed to by the arrows.

We believe that the new evidence is strong enough to confirm the existence of a karst void prior to the basalt injection. Rossi and Zorzin dated the basalt (K/Ar) to $38.2 \pm 1.6 \mathrm{Ma}$, thus providing an ante quem dating of the cave.

\section{OTHER BASALT OUTCROPS}

In addition to the above instances of intrusions in palaeokarst conduits, in the area we observed other occurrences of basalt in cave passages that may, or may not, relate to karst.

Sometimes the basalt was found cross-cutting the cave, as in the cave Bus de la Rana in the Eastern Lessini Mountains. This cave develops between two Formations, Marne di Priabona (late Eocene) and Calcareniti di Castelgomberto (early Oligocene; Antonelli et al. 1990) in 


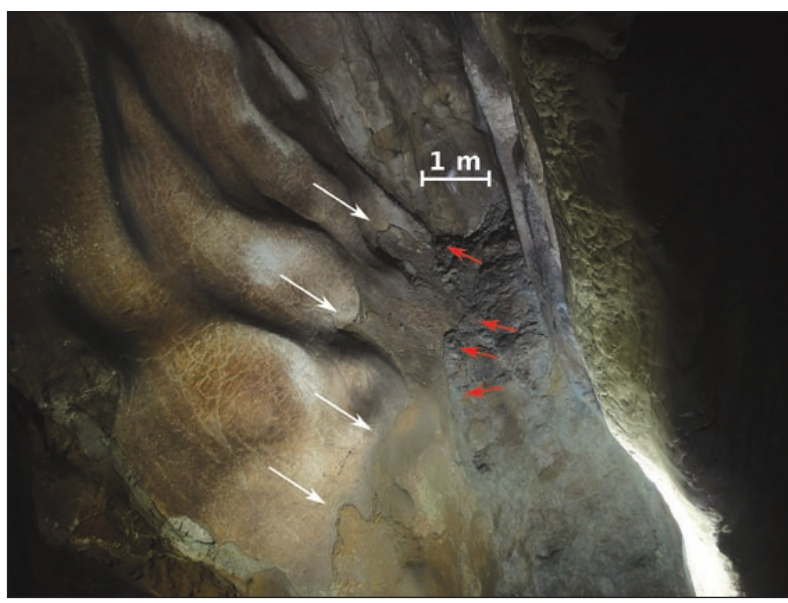

Fig. 12: Ponte di Veja Grotta A: detail of the stretch where the passage wall is partially overlapped by ochre laminations (white arrows). In turn, ochre is overlapped by the basalt intrusion (red arrows).

which thick basalt sills are often interposed (Tisato et al. 2012). The basalt outcrops are clearly unrelated to karst development; their morphology is always rugged and uneven, as can be observed in the case of dykes unrelated to karst.

In other cases, the "dyke or intrusion in karst" problem can be very difficult to solve, or even unresolvable. We have found an unusual basalt exposure that cannot be immediately dismissed as a normal dyke and at the same time cannot be readily interpreted as an intrusion in a cave. The outcrop is exposed at the face of a stocking area cut in the lower Maiolica near Puvel (Roveré), at coordinates N 45.584065, E 11.058504, elevation 715 m (Fig. 13).

The outcrop consists of three connected, roundish basalt lumps, up to $4 \mathrm{~m}$ across. In two of the lumps the basalt is slightly oxidised at the contact with the surrounding limestone, which is not altered. The overall outcrop geometry is definitely unusual for a dyke; all other known basalt outcrops in the area are either cylindrical necks, up to a few hundred metres in diameter, or sheet-like, decimetres-wide sub-vertical dykes. The three basalt lumps are not pillows as they lack the typical shape and radial fracturing pattern.

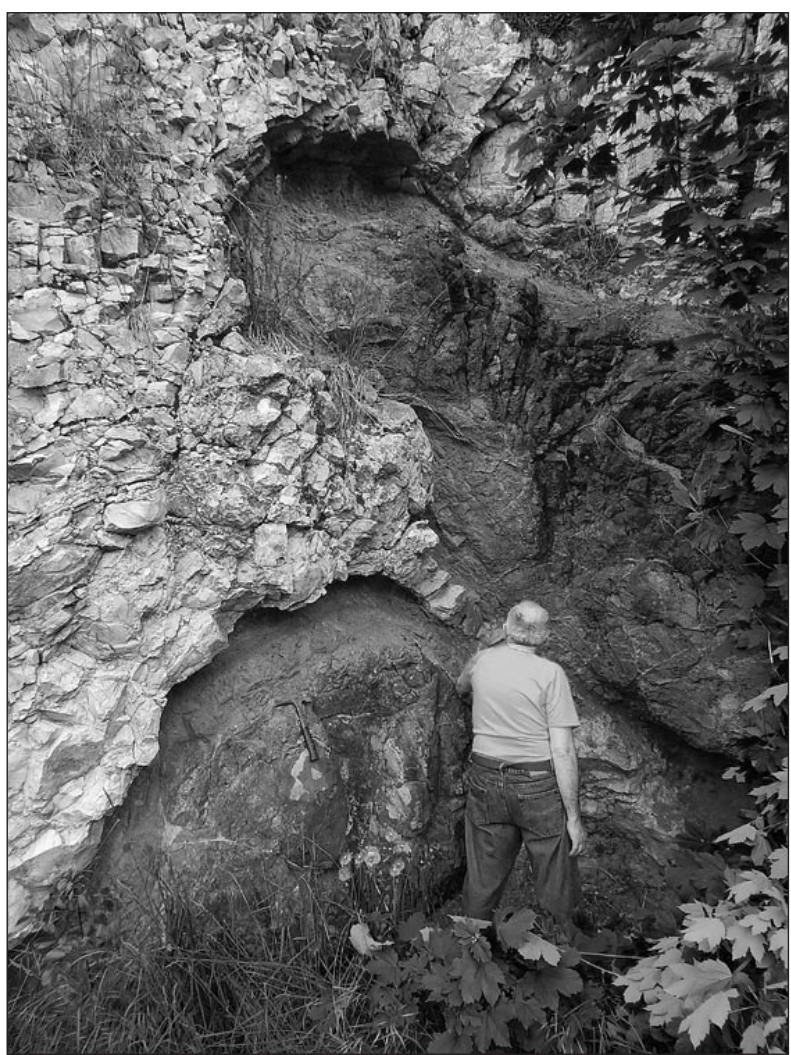

Fig. 13: Two of the three basalt rounded lumps at Puvel.

This outcrop is most probably a normal basalt intrusion which could have penetrated and enlarged a spot where the limestone's mechanical properties were weaker. It should be pointed out, however, that had the basalt been removed by erosion it would have left a rounded void basically indistinguishable from a karst cave. Especially after the growth of speleothems, it would be basically impossible to detect the volcanic origin of this "cave". In fact, an opposite interpretation could also be possible: the basalt might have intruded a pre-existing cave that lacked speleothems or karstic features other than a rounded morphology.

There is no way to provide strong evidence for either interpretation. That said, a cautious application of the Occam's Razor principle should favour a non-karstic, purely volcanic origin as the more likely.

\section{DISCUSSION}

The mere presence of basalt in a cave is obviously not necessarily related to an intrusion. As pointed out by Osborne (2005), special care must be taken to distinguish between palaeokarst and other features that mimic karst morphology. 
In some cases ruling out a relation between basalt and palaeokarst is straightforward. For example, when a cave contains basalt cobbles and there is no visible basalt outcrop, assuming that the cobbles were simply washed in seems reasonable.

Problems may arise when one bases genetic hypotheses on morphologies; in fact, hardly distinguishable morphologies can be originated by very different processes. Let's consider, for example, the basalt intrusion at Grotta A Veja. The shape of a canyon-like karst conduit can be reminiscent of that of a dyke, which is normally described as a sheet-like body enclosed between subparallel walls. If erosion removes the basalt, the remaining void could easily be mistaken for a karst conduit. But if the dyke actually intruded a pre-existing karst cavity, proof of this event can be obtained identifying spots where the basalt overlapped speleothems or other karstrelated sediments, or filled unambiguous karst features such as cupolas, ceiling channels, solution pockets, etc.

We did not find instances of speleothems covered by basalt, but we did find instances of basalt filling ceiling channels (Covoli di Velo) and cupolas (Grotta A Veja, Covolo della Croce, Spigola di Canova). Additional evidence is given by the rounded cross section of the basalt bodies, which is quite comparable to that of karst passages, and by the stalactite fragment embedded in basalt at Covolo della Croce.

Differences in morphology between the basaltfilled conduits in the Central Lessini Mountains and the palaeokarst caves at Torricelle hills near Verona can be highlighted. The former conduits seem to have formed in saturated hydrological environments, while the latter exhibit vadose and epiphreatic structures that formed in a coastal environment (Sauro 2010; Gonzato et al. 2014). The presence of hydrothermal fluids and their role in the speleogenesis of the basalt-filled caves needs further study.

Determining what conditions caused basalt intrusions in the caves is an interesting geological problem; the occurrence of basalt intrusions in caves, in fact, is an uncommon event that requires a set of preconditions.

First and foremost, the presence of carbonate rocks (or other easily karstifiable rocks) is required. Secondly, pervasive fracturing of rocks is needed for the formation of subterranean karst, at least in the case of low-porosity limestones. Besides, fault lines, joints and fractures are planes of weakness that help the intrusion of ascending magma. Obviously, geodynamic conditions favouring the occurrence of volcanism must also be present. Finally, if the affected karst is epigenic, it can only develop in a continental environment.

All of the above conditions were met in the Lessini Mountains. In particular, it should be emphasised that the abundance of basalt dykes was made possible by two concurring causes: the proximity with the volcanic domain to the East of the Castelvero fault, and the extensive fracturing caused by tectonics. Considering the low probability that a volcanic flow intrudes a cave, one could presume that the karst network was already well developed when late Eocene volcanism took place. The basalt intrusions provide an ante quem dating of the caves they intruded and consequently of the marine regression that led to the emergence of part of the Lessini Mountains.

\section{CONCLUSIONS}

We have studied some occurrences of basalt intrusions in palaeokarst conduits which were recognised in longknown caves in the Lessini Mountains.

In caves Covoli di Velo, Covolo della Croce, Spigola di Canova, and Grotta A Veja the morphologies of the basalt filled passages clearly indicate a karstic origin; the basalt therefore intruded pre-existing voids. In particular, the basalts at Covoli di Velo occlude ceiling channels, thus revealing polyphase cave development that included an epiphreatic stage; the possibility of hypogenetic speleogenesis needs further investigation. The basalt intrusions at Covoli di Velo and Ponte di Veja (dated respectively $33 \pm 1.5$ and $38.2 \pm 1.6 \mathrm{Ma}$ ) provide therefore firm evidence that karst development occurred in the central Lessini plateau already before the early Oligocene. This dating is in good agreement with the one provided by Gonzato et al. (2014) for one of the palaeokarst caves in the Torricelle hills, which was dated to the late Eocene by means of its fossiliferous contents. Basalt at Covolo della Croce and Spigola di Canova have not yet been used for $\mathrm{K} /$ Ar dating; petrographical and mineralogical analysis of the basalts of all outcrops will be the subject of further study.

In another case the morphology is ambiguous. The basalt "bubbles" at Puvel apparently intruded a pre-existing rounded cavity; the morphology is quite different from that of normal basalt dykes in the area, but there is no conclusive evidence of pre-existing karst. In general, to ascertain whether or not a basalt outcrop in a cave is 
a palaeokarst fill, the presence of irrefutable karst morphologies is required.

With over 750 caves known in the Lessini Mountains, the task of re-checking them all to assess the pres- ence of basalt intrusions, ochre fills, and unusual morphologies is quite intimidating. Local cavers, a very special and highly trained kind of "citizen scientist", can be extremely helpful in this case.

\section{ACKNOWLEDGMENTS}

The authors would like to thank the caving team Unione Speleologica Veronese for providing caving equipment and invaluable technical support; in particular, Eddy Albertini and Marco Frigo rigged the climb to the vault of Grotta A Veja. We are grateful to prof. Alberto Castellarin (University of Bologna) for his useful observations on the Puvel outcrop. We also wish to thank Fiorenzo and Giorgio Annichini, Francesco Bellamoli, Michele Girardi, Fabio Pomarelli, Carlo Rebonato, and Giampaolo Zago, who completed the new survey of the Covoli di Velo complex. We thank two anonymous reviewers whose suggestions and corrections were precious to improve this paper. Finally, many thanks to Anita Gubbiotti who carefully revised the English text.

\section{REFERENCES}

Antonelli, A., Barbieri, G., Dal Piaz, G.V., De Zanche, V., Grandesso, P., Mietto, P., Sedea, R. \& A. Zanferrari, 1990: Carta Geologica del Veneto 1:250.000: una storia di cinquecento milioni di anni.- S.E.L.C.A., pp. 32, Firenze.

Assorgia, A., Bentini L. \& C. Dernini, 1968: Nuove conoscenze sulle grotte costiere del settore di Cala di Luna (Dorgali - Sardegna Orientale).- Atti del X Congr. Int. di studi sardi, Cagliari, 10, 4-26.

Bartolomei, G. \& A. Broglio, 1975: Risultati preliminari delle nuove ricerche nei depositi quaternari della Grotta A di Veja.- Bollettino Museo Civico di Storia Naturale Verona, 1, 217-238.

Benetti, A., 1973: La distruzione dei depositi quaternari dei "Covoli di Velo" nei Monti Lessini Veronesi.Natura Alpina, Trento, 24, 1, 27-37.

Benetti, A. \& F. Sauro, 1999: Storia delle ricerche sul complesso carsico dei Covoli di Velo.- In: Atti Tavola Rotonda "Un importante sistema carsico dei Monti Lessini (VR): $i$ Covoli di Velo, $16^{\text {th }}-17^{\text {th }}$ April 1999, Camposilvano. Museo Civico di Storia Naturale Verona, 5-12, Verona.

Bosák, P., Ford, D.C., Głazek, J. \& I. Horáček (eds.), 1989: Paleokarst - A Systematic and Regional Review. Elsevier Science, pp. 726, New York.

Broglio, A., Laplace, G. \& F. Zorzi, 1963: I depositi quaternari del Ponte di Veja. Le industrie.- Mem. Mus. Civ. St. Nat. Verona, XI.
Castellarin, A. \& L. Cantelli, 2000: Neo-Alpine evolution of the Southern Alps.- Journ. of Geodyn., 30, 1-2, 251-274. DOI: http://dx.doi.org/10.1016/S02643707(99)00036-8

Cavallo, G., Riccardi, M.P. \& R. Zorzin, 2015: Powder diffraction of yellow and red natural earths from Lessini Mountains in NE Italy.- Powder Diffraction, 30, 2, 122-129. DOI: https://doi.org/10.1017/ S0885715614001407

Conato, V. \& B. Martinis, 1955: Osservazioni sul miocene dei colli veronesi e vicentini.- Riv. It. Paleont. Strat., 61, 2, 1-13.

Corrà, G., 1977: Osservazioni sui fenomeni paleocarsici terziari nei calcari eocenici delle colline di Verona.Studi Trent. Sc. Nat., Geologica, 54, 123-142.

Dal Molin, L., Mietto, P. \& U. Sauro, 2000: Considerazioni sul paleocarsismo terziario dei Monti Berici: la Grotta della Guerra a Lumignano (Longare, Vicenza).- Natura Vicentina, 4, 33-48.

De Zanche, V., Sorbini, L. \& V. Spagna, 1977: Carta geologica del territorio del Comune di Verona.- Mem. Mus. Civ. St. Nat. Verona, II, sez. Sc. della Terra, 1.

Fabiani, R., 1919: Guida geologica delle colline di Verona.- Mem. Acc. Agric. Sc. e Lett. Verona, XXI, 4, 241-252.

Forlati, F., 1978: Aspetti geologici dei giacimenti di terra gialla sulla collina di Verona.- Boll. Mus. Civ. St. Nat. Verona, 73-85. 
Fortis, A., 1785-1786: Extrait d'une lettre de M. l'abbé Fortis datée de Vérone le 24 Septembre 1785 à M. le Comte de Cassini de l'Académie des Sciences sur différentes pétrifications.- J. Phys., 28/I, 161-168.

Gonzato, G., Castellarin, A., Chignola, R., Gamberini, F., Lazzeri, P. \& Unione Speleologica Veronese, 2014: New dating of palaeokarst features at Torricelle hills (Verona, Italy).- It. Journ. Geosc., 133, 3, 427-438. DOI: http://dx.doi.org/10.3301/IJG.2014.14

James, N.P. \& P.W. Choquette (eds.), 1988: Paleokarst.Springer, pp. 416, New York.

Mahler, A., 1979: Verkarstung der Karbonatgebiete am Golfo di Orosei (Sardinien).- Geol. Paläeont. Mitt. Innsbruck, 7, 8-9, 1-49.

Mietto, P. \& U. Sauro, 2000: Le Grotte del Veneto: paesaggi carsici e grotte del Veneto.- Regione Veneto \& La Grafica Editrice, pp. 480, Vago di Lavagno, Verona.

Osborne, R.A.L., 1986: Cave and landscape chronology at Timor Caves, New South Wales.- Journal and Proceedings of the Royal Society of New South Wales, 119, 1-2, 55-76.

Osborne, R.A.L., 2005: Dating ancient caves and related palaeokarst.- Acta Carsologica 34, 1, 4, 51-72. DOI: http://dx.doi.org/10.3986/ac.v34i1.279

Pasa, A., 1950: I depositi quarternari del Ponte di Veja.Mem. Museo Civ. St. Nat. Verona, 2, 241-308.

Pasa, A., 1954: Carsismo e idrografia carsica nel Gruppo del Monte Baldo e nei Lessini Veronesi.- Tip. Mareggiani, pp. 150, Bologna.

Piccoli, G., 1966: Studio geologico del vulcanesimo palaeogenico veneto.- Mem. Ist. Geol. Miner. Univ. Padova, 26, 1-100.

Riva, A., 2014: Hypogene Paleokarst in the Triassic of the Dolomites (Northern Italy).- In: Klimchouk, A. et al. (eds.) Hypogene Cave Morphologies, Selected papers and abstracts of the symposium, $2^{\text {nd }}-7^{\text {th }}$ February 2014, San Salvador Island, Bahamas. Karst Waters Institute, 97-100, Leesburg, Virginia.

Rossi, G. \& R. Zorzin, 1986: Underlining an interesting paleokarstic phenomenon in the Lessini (Prealpi Venete - Northern Italy).- In: Comun. 9 Congr. Int. de Espeleologia, 1986, Barcelona. Barcelona, 290293.

Rossi, G. \& R. Zorzin, 1991: Nuovi dati sui fenomeni paleocarsici dei Covoli di Velo (M.ti Lessini - VR).In: Atti XVI Congresso Nazionale di Speleologia, 1990, Udine. Udine, 169-174.
Rossi, G. \& R. Zorzin, 1993: Nuove osservazioni sul complesso carsico del Ponte di Veja (M.ti Lessini VR).- In: Le Grotte d'Italia. Atti XV Congresso Nazionale di Speleologia, 1990-1991, Udine. Udine, 41-49.

Sauro, U., 1973: Il Paesaggio degli alti Lessini: Studio geomorfologico.- Mem. fuori serie, 6, Mus. Civ. St. Nat. Verona, pp. 160, Verona.

Sauro, U., 1974: Aspetti dell'evoluzione carsica legata a particolari condizioni litologiche e tettoniche negli Alti Lessini.- Boll. Soc. Geol. It, 93, 945-969.

Sauro, U., 2001: Aspects of contact karst in the Venetian fore-Alps.- Acta carsologica 30/2, 5, 89-102

Sauro, U., 2010: Lessinia.- Cierre edizioni, pp. 280, Verona.

Scarzella, P. \& P. Natale, 1989: Terre coloranti naturali e tinte murali a base di terre: monografie e catalogo delle collezioni di terre coloranti e di campioni di coloriture a base di terre allestite al Politecnico di Torino.- Stamperia Artistica Nazionale, pp. 92, Torino.

Tarquini, S., Isola, I., Favalli, M., Mazzarini, F., Bisson, M., Pareschi, M.T. \& E. Boschi, 2007: TINITALY/01: a new Triangular Irregular Network of Italy.- Annals of Geophysics, 50, 3, 407-425. DOI: http://dx.doi. org/10.4401/ag-4424

Tisato, N., Sauro, F., Bernasconi, S., Bruijn, R.H.C. \& J. De Waele, 2012: Hypogenic contribution to speleogenesis in a predominant epigenic karst system: A case study from the Venetian Alps, Italy.- Geomorphology, 151, 156-163. DOI: http://dx.doi. org/10.1016/j.geomorph.2012.01.025

Zorzin, R., Accorsi, C.A., Bandini Mazzanti, M. \& M. Di Giuseppe, 1992: Nuovi dati geologici e palinologici sul paleocarsismo delle terre coloranti dei Monti Lessini - Verona.- Boll. Mus. Civ. St. Nat. Verona, 19, 475-503.

Zorzin, R., 2005: Le terre coloranti dei Monti Lessini.In: Broglio, A. \& G. Dalmeri (eds.) Pitture paleolitiche nelle Prealpi venete. Mem. Mus. Civ. St. Nat. Verona, 2, 9, 47-50.

Zorzin, R. \& G. Rossi, 2006: Gli scavi nei depositi pleistocenici dei Covoli di Velo (VR): elementi per una ricostruzione dell'evoluzione del sistema carsico.Boll. Mus. Civ. St. Nat. Verona, 30, 2006, Geol. Paleont. Preist., 3-9. 